\title{
The Birth of Representative Institutions: The Case of the Crown of Aragon
}

\section{Jørgen Møller}

A new research agenda within political science and economics has been devoted to elucidating the development of medieval representative institutions. However, if we wish to get a clearer grasp of the birth of representative institutions, much more detailed data are needed. This paper introduces and interrogates a new data set on assemblies in one of the first instances where representative institutions arose: the Crown of Aragon. An analysis of these new data, which cover the period 1100-1327, supports several important conclusions. First, the development of representative institutions took place in a couple of brief "bursts" of activity. Second, factors pertaining to the establishment of public order (land peace and the regulation of succession) feature as more important than "geopolitical" factors (war and taxation) in the early part of the period, but the latter factors become more important after assemblies turn representative; indeed, they turn out to be crucial for understanding how assemblies eventually came to constrain rulers. A comparison with the only other early case of representative institutions on which there are good data, thirteenth-and early-fourteenth-century England, supports a third finding: There is a striking, temporal parallelism in the development of representative institutions across the two realms.

\section{Introduction}

An influential body of scholarship traces present-day divergences in economic and political trajectories to the European "institutions of constraints" that arose in the Middle Ages and were transplanted to a series of European colonies following the overseas voyages after 1500 (Acemoglu and Robinson 2012; Acemoglu et al. 2001, 2002a, 2002b; Downing 1992; Hariri 2012; Jones 2008 [1981]). The key observation of this literature is that these institutions, by placing constraints on executives, were conducive to both economic growth and democratization. A recent outgrowth of this literature has been a series of attempts to elucidate the origins and character of the medieval parliaments that lie at the core of these institutions (Abramson and Boix 2014; Blaydes and Chaney 2013; Boucoyannis 2015; Møller 2014; Stasavage 2010, 2011, 2016; Van Zanden et al. 2012).

This scholarship has provided several important insights into the development of representative institutions. However, it has had some important blind spots that seem to owe to the fact that the very attempt to understand origins has been sparked by the notion that these institutions would later come to place constraints on executives - that is, monarchs. This vantage point has made scholars read history "backward" rather

\footnotetext{
*I am indebted to Andrej Kokkonen, Agnes Cornell, David Andersen, Svend-Erik Skaaning, Thomas Ertman, and three anonymous reviewers at Social Science History for critical comments. I also thank Lars Kokholm and Suthan Krishnarajan for research assistance.
} 
than "forward" (see Capoccia and Ziblatt 2010: 939-42), which probably explains why virtually all extant analyses of the origins of representative institutions emphasize factors that affected the power of the social forces that confronted monarchs. These include the character of local government at the outset of medieval state building, geographical size, the military functions of nobles, the communal revolution, and the split between religious and secular power (Abramson and Boix 2014; Blaydes and Chaney 2013; Ertman 1997; Hintze 1975 [1931]; Møller 2014; Poggi 1978; Stasavage 2010, 2016; Van Zanden et al. 2012). The theorizing of these factors has usually been couched in the more general insight that-in the context of intensified geopolitical competition-monarchs summoned representative institutions to make key elite groups consent to warfare and taxation (Bisson 1966; Finer 1997; Hintze 1975 [1931]; Poggi 1978; Schumpeter 1991 [1917/1918]; Tilly 1990). However, this "geopolitical" or "fiscal" line of inquiry likewise mainly focuses on the social groups that have been seen to use these institutions to rein in monarchs as a quid pro quo for assenting to taxation.

This backward-looking perspective has made scholars ignore that the assemblies that gradually turned into representative institutions were originally created in a topdown manner by monarchs. Indeed, the prerogative of summoning assemblies was entirely a regalian right (Maddicott 2010: 141; O'Callaghan 1975: 439). Bisson (2009: 559) accordingly construes the early assemblies as "implements of lordship." Only later on did they evolve into the kinds of constraints on monarchs on which most of the recent literature focuses. To obtain a more correct understanding of the development of representative institutions, we therefore need to analyze the process that brought these institutions into being in a forward-moving fashion. This will allow us to understand why monarchs first chose to call assemblies and how and why these assemblies later came to constrain monarchs. It will allow us to understand the more general process in which the initiative behind the summoning of representative institutions slipped from the monarch to the elite groups as political counsel came "to be recognized as a right as well as an obligation by the people summoned to give it" (Bisson 1966: 1206).

We actually find one recent attempt to analyze the development of representative institutions in this way. Boucoyannis uses a forward-looking approach to argue that assemblies were summoned by rulers to commit key groups (a compellence perspective), not orchestrated by elite groups to rein in monarchs (a bargaining perspective). In this connection, Boucoyannis points out that we need to distinguish between how institutions emerge and how they further develop, and that different causes might be operating in these different stages. More particularly, Boucoyannis argues that a high level of state capacity was necessary for forcing through representation in the initial stage, where we find little or no evidence of bargaining — a point that the dominant (backward-looking) fiscal perspectives on the origins of representative institutions have ignored.

This paper takes a similar starting point for understanding the birth of representative institutions. As we shall see, the findings challenge Boucoyannis's argument about the importance of state capacity for creating representative institutions. But the paper strongly endorses her approach. It enlists new, fine-grained data on 
assemblies in one of the earliest places where representative institutions arose. This is the Crown of Aragon, which spanned the kingdom of Aragon and the county of Catalonia from 1137 and to which the kingdom of Valencia was added in 1238. ${ }^{1}$ The most important conclusions to be drawn from the new data are that "geopolitical" factors (war and taxation) were of negligible importance in the early stages of the development that culminated in representative institutions. Instead, the establishment of public order (land peace and the regulation of succession) is by far the most prominent cause for summoning the assemblies of notables that preceded genuine representative institutions. However, once we focus on representative institutions and particularly the assemblies in which parliamentary prerogatives were granted, taxation becomes much more prominent as a cause. And when we hone in on the crucial periods of constitutional development, warfare looms as the major explanatory factor.

The paper proceeds as follows. First, I introduce a new data set that contains detailed information about the development of assemblies in Aragon, Catalonia, and Valencia in the period 1100-1327. Second, I interrogate this data set in an attempt to establish both the descriptive development of these assemblies and the causes for summoning them in the various stages of their development. Third, I discuss the extent to which the findings can travel beyond the Crown of Aragon. To do so, I enlist additional data describing the early phases of the English parliament.

\section{A New Data Set on Assemblies in the Crown of Aragon, 1100-1327}

A forward-looking analysis of the birth of representative institutions requires much more detailed data on individual cases than what is present in extant data sets (see following text). But which cases should such an investigation focus on? As Marongiu (1968: 76) pointed out long ago, the Iberian and English cases deserve particular scrutiny because of the light they throw on the origins of representative institutions. These were the earliest instances of medieval parliaments (see also Myers 1975: 24; Poggi 1978; Van Zanden et al. 2012). Studying these cases allows us to be present at creation, thus decreasing the risk that identified developments are the product of demonstration effects in the form of diffusion of ideas and institutions. This is what Van Zanden and colleagues (2012: 839) recognize when they observe that it is unclear whether the spread of representative institutions from the Iberian Peninsula to the rest of Western and Central Europe is a product of "copying of this institution, or of parallel evolution under similar circumstances."

More particularly, two cases emerge as particularly well suited for the kind of forward-looking analysis sketched in the introduction; namely, the Crown of Aragon

1. In time, it also came to comprise several Mediterranean possessions, such as Sicily from 1282 , but the data set only covers the three Iberian units of the Crown of Aragon. 
and England. What is particularly fascinating about these cases is that both the royal archives of Aragon and the curia regis rolls of England have survived (Kagay 1981: 1; Procter 1980: 2). ${ }^{2}$ This means that virtually all assemblies have been registered and that we have information about the reasons for summoning assemblies. We can look for interesting patterns in how often these reasons apply and cross-tabulate these with (1) summoning of assemblies of notables, (2) convocations of genuine representative assemblies, and (3) the assemblies in which certain prerogatives were first extracted from rulers.

To capture the development of representative institutions in these cases empirically, some preliminary conceptual distinctions are needed. First, to understand the development of medieval assemblies, it is necessary to begin with the assemblies of notables that preceded and provided the seeds of the later representative institutions almost everywhere in Latin Christendom (Kagay 1981; Maddicott 2010; Marongiu 1968; O’Callaghan 1989; Procter 1980). Marongiu (1968: 52-53) contrasts these preparliaments with genuine parliaments, a distinction that will also be used in this paper, although I refer to the latter simply as representative institutions. Second, representative institutions only came to genuinely constrain monarchs once they gained a series of prerogatives, which had earlier been exclusively regalian, including rights of fixed convocations (Kagay 1997: 32; Stasavage 2010). These, too, needs to be registered. Third, we need disaggregate data because both the "type switch" (Poggi 1978) from preparliaments to representative institutions and the later consolidation of representative institutions often took place in relatively brief bursts, sometimes during a few crucial decades or even just a few crucial years. Fourth, we need these data for the constituent units of the "composite states" of late medieval Europe where the most important interactions between rulers and elite groups took place (cf. Abramson and Boix 2014: 10-11).

Measured against these standards, present data sets on representative institutions are deficient in four regards (see, e.g., Abramson and Boix 2014; Stasavage 2010; and Van Zanden et al. 2012). First, they do not register the assemblies of notables (preparliaments) previously mentioned but only tally genuine representative institutions. ${ }^{3}$ Second, most of the present data sets are based on aggregate spatial units such as "Spain" or "France." Third, most of the present data sets only provide scores for aggregated time periods such as 50-year periods or centuries (e.g., Stasavage 2010; Van Zanden et al. 2012). Fourth, extant data sets have primarily charted the frequency

2. This distinguished these realms from the third candidate for an early instance, Leon-Castile, where the royal archives have not survived for the medieval period (Procter 1980: 2).

3. In the cases of Stasavage (2010) and Van Zanden and colleagues (2012: 837), it is only with the advent of urban representatives that an assembly is tallied. Abramson and Boix (2014) do register assemblies without urban representatives but only if these assemblies are independent of the executive, i.e., not directly appointed by the executive. These restrictions of course reflect that these scholars are only interested in coding genuinely representative institutions. But the fact remains that such a truncation makes it difficult to understand origins, considering that representative institutions evolved gradually from assemblies of notables. 
of convocations, not the development in parliamentary prerogatives or the reasons for summoning assemblies. ${ }^{4}$

Against this background, I have compiled a new data set tallying preparliaments and representative institutions in the Crown of Aragon from 1100 to 1327. This data set is based on a particular historical source: Kagay's (1981) narrative descriptions of all assemblies in the Crown of Aragon from 1064 to 1327. As Kagay (1981: 35657) points out, this period spans the development from assemblies of notables to genuine representative institutions, which came to colegislate with rulers. Dr. Kagay has confirmed that the dissertation maps all relevant assemblies in this period. ${ }^{5}$

The data register assemblies in the three constituent units of the kingdom of Aragon, the county of Catalonia, and the kingdom of Valencia. A more aggregate unit is also covered, namely Aragon-Catalonia or (later) Aragon-Catalonia-Valencia. Aragon and Catalonia both enter the data set in 1100 even though they were only joined into one realm in 1137. Aragon-Catalonia enters after this date whereas Valencia (and consequently Aragon-Catalonia-Valencia) enters in 1238 after being conquered from the Muslim states in Southern Spain.

For each of these five political units, the data set includes information on the following: (1) the place and date of the assembly as well as the monarch who called it; (2) whether it was a representative institution (coded 1) or a preparliament (coded $0)$; (3) whether each of the following groups was summoned: clergy, nobles, townsmen (coded as 1 if present, 0 if absent); (4) whether any of following five prerogatives were granted by the monarch: fixed convocations, the right to audit expenditure, veto on declaring war, the right to be in charge of adjudication, and the right to appoint royal officials (coded as 1 if granted, 0 if not granted); and (5) whether one or more of the following reasons for summoning the assembly applies: taxation (not related to coinage), coinage, land peace, war, and succession (coded as 1 if they apply, 0 if not). Finally, the data set contains the category "other," in which more idiosyncratic reasons for summoning are reported in narrative descriptions.

The most difficult decision was to determine whether an assembly was a representative institution or not. Here, I have followed the convention to score the assembly as such if towns sent genuine representatives (proctors), normally appointed by the town councils (Marongiu 1968; Stasavage 2010; Van Zanden et al. 2012). The data set includes several preparliaments in which townsmen attended but did not arrive as genuine representatives of their town councils. These are not tallied as representative. With respect to prerogatives, I have only coded the instances (always representative institutions) where these were explicitly granted by the monarch; that is, I have only coded what I will term constitutional concessions by monarchs. In several of the political units of the Crown of Aragon, such concessions occur repeatedly for

4. There are some exceptions. Abramson and Boix (2014) code assemblies on a relatively disaggregate spatial level and on a yearly basis whereas Stasavage (2010) has coded prerogatives such as veto over taxation and the right to audit expenditure. However, Abramson and Boix's data have not been released, and in any case, they only cover the frequency of convocations whereas Stasavage's data fail the requirement to disaggregate units both spatially and temporally.

5. E-mail correspondence, May 12, 2015. 


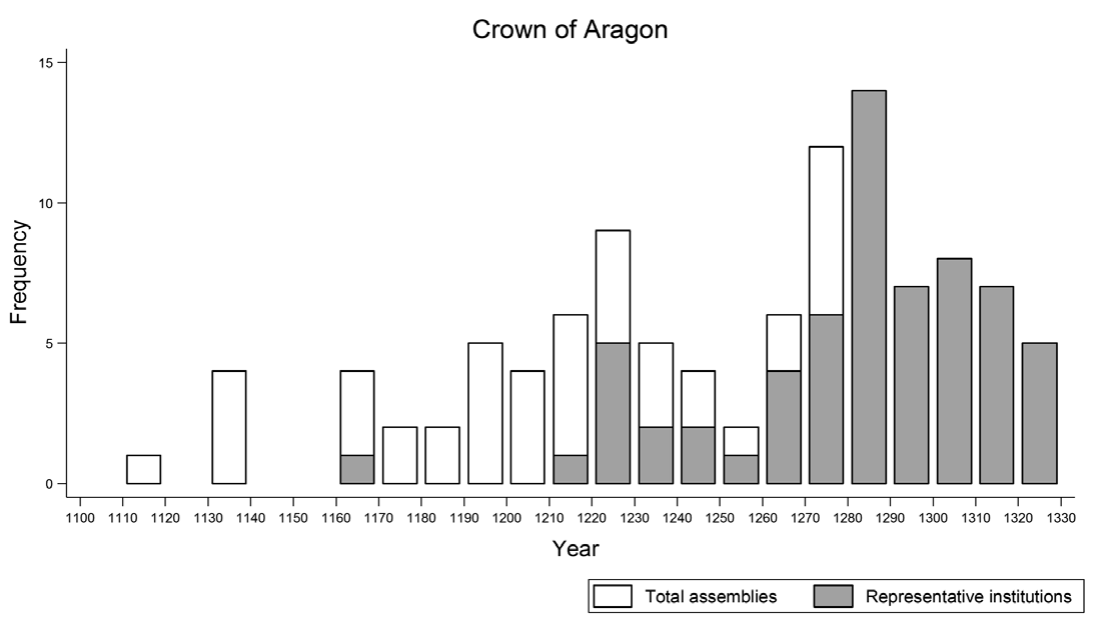

FIGURE 1. Preparliaments and representative institutions by decade, the Crown of Aragon, 1100-1327.

the same prerogatives, underscoring that they were often not observed by monarchs and therefore had to be fought for over again. ${ }^{6}$ The online appendix details coding decisions and attempts to ensure intercoder reliability.

The data set presents several advantages over Kagay's (1981) purely narrative descriptions. Most importantly, it makes it easier to capture general patterns andrelated to this - to avoid overemphasizing exceptions. To illustrate, Kagay (1981: 41, $87,115,361-62$ ) repeatedly argues that his descriptions corroborate Bisson's (1966) classical claim that the assemblies that became representative were originally military in nature. When interrogating the data set, however, it is obvious that Kagay does so on the basis of the kind of confirmation bias according to which, each time this was the case, it is emphasized without considering the low frequency of especially preparliaments convoked for military purposes. As we shall see in the following text, war was an infrequent reason for summoning assemblies in the early period and only became prominent at a later stage.

\section{From Preparliaments to Genuine Representative Institutions}

Figure 1 presents the overall frequencies for assemblies in the Crown of Aragon in the period 1100-1327 and breaks these down on the instances that were representative institutions and those that were not. We find a total of 107 assemblies in this

6. Boucoyannis (2015: 12) makes a similar observation about the English case in which the repeated reconfirmations of Magna Carta in the thirteenth and fourteenth centuries reflect that its promises were repeatedly broken by Plantagenet monarchs. 

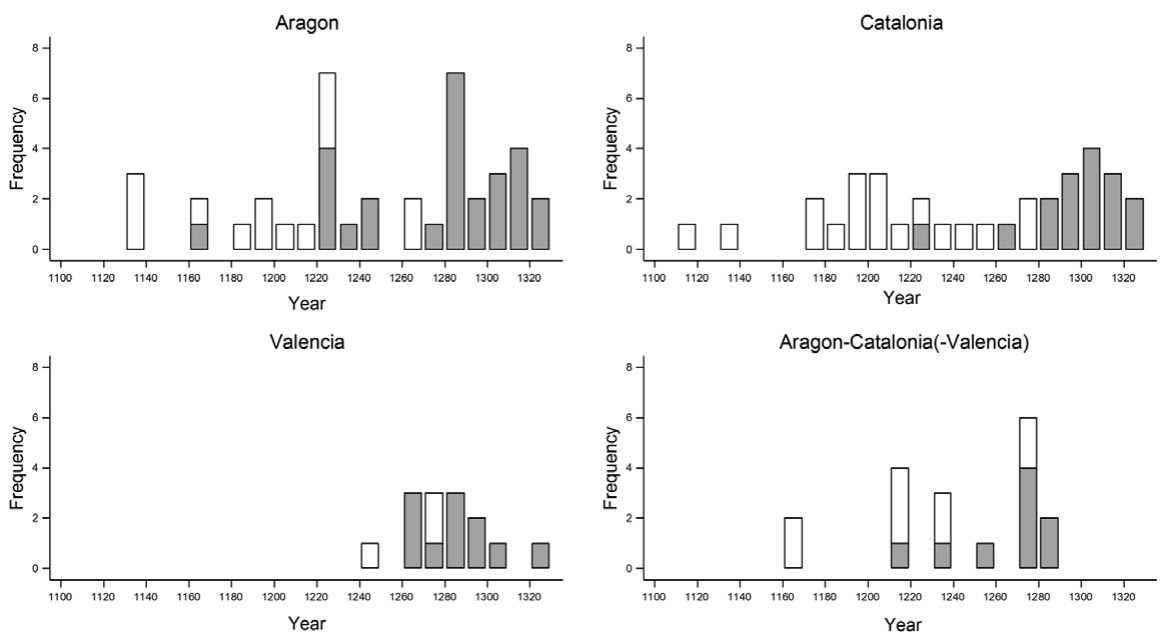

FIGURE 2. Preparliaments and representative institutions by decade, constituent units of the Crown of Aragon, 1100-1327.

period; 39 of these can be categorized as preparliaments; 63 can be characterized as representative institutions; and the last five are unspecified. ${ }^{7}$ In figure 2 , these tallies are further broken down on the three units of Aragon, Catalonia, and Valencia and the composite unit of Aragon-Catalonia(-Valencia).

Figure 1 shows that the assemblies are not spread evenly across time. A first cluster of assemblies is registered in the 1130s, but not until the 1160s onward are assemblies (in the form of preparliaments) regularly summoned. More generally, across the Crown of Aragon, we find particularly high frequencies of convocations in the periods 1217-36 (18), 1275-93 (30), and 1307-25 (15).

Next, we can note that the first of these three periods is also the one in which representative institutions started to supplant preparliaments. The first representative institution is convoked as early as 1164 in Aragon. This assembly took place 24 years before the more famous one called by Alfonso IX upon his accession to the Leonese throne in 1188, which is normally considered the first representative institution in medieval Europe (Marongiu 1968: 61-62; Van Zanden et al. 2012: 838). However, based on Kagay's (1981: 41-42) distillation of the sources, we must conclude that townsmen attended the assembly in Zaragoza on November 1164 as genuine representatives of their town councils, albeit their status was not as precisely defined (by Roman law) as it would become in the thirteenth century.

However, the 1164 assembly in Zaragoza was in some ways a false start. Not until the joint Aragonese-Catalonian assembly in Lérida in 1214 - which Procter (1980: 255), for instance, identifies as the first assembly with town representatives in the Crown of Aragon-do we find another representative institution, and the first purely

7. In the figures, the five unspecified assemblies are included in the total number of assemblies. 

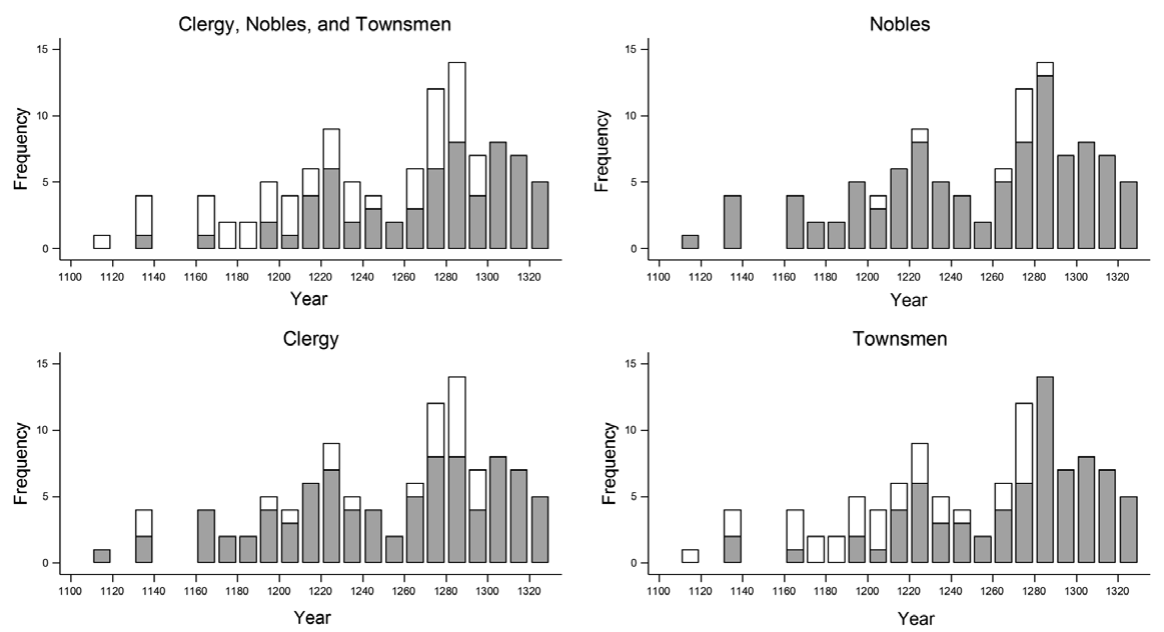

FIGURE 3. Frequencies of groups participating in assemblies by decade, the Crown of Aragon, 1100-1327.

Catalonian representative institution can be dated to 1228 (meeting in Barcelona). From that time onward, we regularly encounter representative institutions in all constituent units of the Crown of Aragon (see also Bisson 1986: 64-66). This development does not spell the end of preparliaments. For quite some time, the two types of assemblies coexisted. But representative institutions increasingly supplanted preparliaments.

Turning to similarities and differences between the three constituent units and the superunit of Aragon-Catalonia(-Valencia), we see a rather even development across the two major units of Aragon and Catalonia. Aragon had 41 assemblies between 1100 and 1327, 27 of which were definitely representative; Catalonia trails slightly with 34 assemblies, 16 of which were definitely representative. These proportions match those of the superunit of Aragon-Catalonia(-Valencia), which saw 18 assemblies in the same period, 9 of which were representative. The distribution is more skewed in Valencia for the simple reason that this unit enters relatively late-at a point in time when representative institutions had largely replaced preparliaments.

As previously mentioned, the data set also registers which groups attended the assemblies. These tallies are illustrated in figure 3 (the number of assemblies where a particular group or combination of groups attended is indicated with grey). Most interesting is the pattern of urban representation. We see, first, that urban representation was exceptional before 1200, second, that it began to be the norm in the first of three periods singled out in the preceding text, 1217-36, and, third, that the second period, 1275-93, marks the juncture where townsmen began to partake in all assemblies. In the period from 1100 to 1200 , when urban representation was still exceptional, the 
most frequent combination is the summoning of clergy and nobles. This pattern was especially frequent in Catalonia.

Summing up, we can say that in the Crown of Aragon, the preparliament stage lasts into the first quarter of the thirteenth century. The half century between 1214 and 1265 is a transition phase where the count-king begins to call group members as genuine representatives of estate groups. This paves the way for genuine representative institutions. However, the most interesting period - with most frequent convocations - does not begin until the last quarter of the century.

More particularly, three periods of high frequency of convocations have been identified: 1217-36, 1275-93, and 1307-25. No less than 63 (close to 59 percent) out of 107 of the assemblies identified in the period 1100-1327 were convoked during these 58 years, ${ }^{8}$ with a particular high intensity in the years between 1275 and 1293 (28 percent of all assemblies). It is also revealing that no less than 6 out of the 18 assemblies of the superunit of Aragon-Catalonia took place in this period (with another five occurring in the period 1217-36). Finally, townsmen began to be summoned regularly in the first period and to be ubiquitously present in the second period. This can be seen as further evidence of the general political conflicts fermenting in these three spells of time, which we return to in the following text.

\section{From Land Peace and Succession to War and Taxation}

First, however, it is pertinent to obtain a more general grasp of the specific reasons for summoning first preparliaments and later genuine representative institutions over the entire period 1100-1327. ${ }^{9}$ As illustrated in figure 4, it turns out that the reasons for summoning (the early) preparliaments differ fundamentally from the reasons for summoning (the later) representative institutions.

Figure 4 tallies how often land peace, succession, war, and taxation, respectively, occasioned assemblies (the number of assemblies where a particular reason applies is indicated with grey). The figure does not directly feature the distinction between preparliaments and representative institutions, but indirectly it does because of the stark temporal pattern identified in the preceding text.

Figure 4 shows that by far the most important reason for convening early assemblies was to establish a land peace (pax et treuga). This institution had been appropriated from Church practice (pax et treuga Dei) in Catalonia in the eleventh century (Kagay 2003: 61). The land peace was needed because eleventh- and twelfth-century Aragon and Catalonia were pervaded by anarchy_or "private wars" — with castellans regularly inflicting violence on each other, each other's dependents, and passersby (Bisson 1986, 2009; Kagay 1981, 2003: 60-61). Establishing a land peace was

8. This is to some extent a consequence of a more general increase in the frequency of convocations over time. But the three periods are interspersed with periods of less parliamentary activity, which this general trend cannot explain.

9. Several different reasons for summoning can apply to the same assembly, but one reason can obviously only be scored once for each assembly (see the online appendix). 

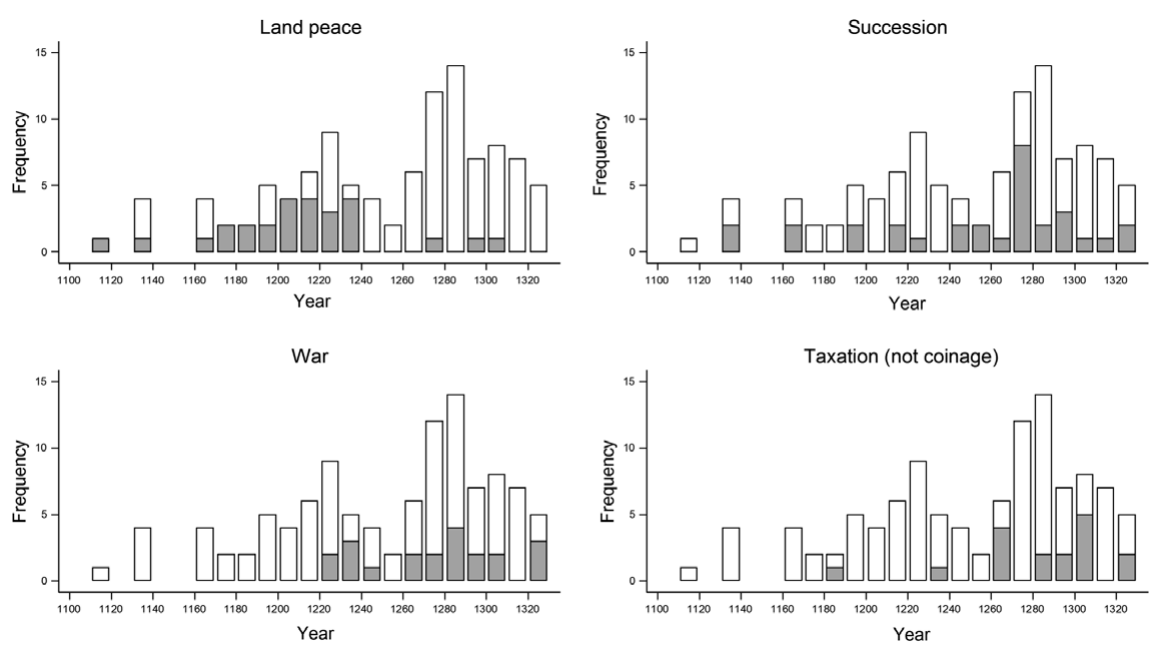

FIGURE 4. Reasons for summoning assemblies by decade, the Crown of Aragon, $1100-1327$.

especially common in Catalonia. If we invoke the distinction between preparliaments and representative institutions, it turns out that in Catalonia, no less than 73 percent of the former were convoked with this aim. We also find a high proportion of such preparliaments in Aragon-Catalonia (44 percent) and-albeit to a lesser extent-in Aragon (21 percent).

The second most important reason for summoning early assemblies is succession. In the preparliament phase, this reason was especially prominent in the superunit of Aragon-Catalonia (33 percent) but also quite common in Aragon (29 percent). Taken together, 23 percent of all preparliaments in the Crown of Aragon were summoned to either confirm a new monarch or to confirm the right of a designated heir to the throne. Furthermore, among the five unspecified assemblies, where it cannot be determined whether they were preparliaments or representative institutions, no less than four dealt with succession (and none dealt with any other reason).

As shown in figure 4, war and taxation turn out to be much less frequent reasons for summoning early assemblies (and hence preparliaments), even though both reasons are registered on a few occasions. This finding underscores that assemblies were first convoked by monarchs in a top-down manner to facilitate lordship. More precisely, in the Crown of Aragon, these assemblies served two main purposes: to establish land peace and preempt conflicts over succession to the throne. Both factors have been noted as important by historians (Bisson 1986, 2009; Kagay 1981; O'Callaghan 1989; Procter 1980), but so far, they have left little trace in the new political science and economics literature on representative institutions described in the introduction.

With respect to the early phase of assemblies, the standard explanations posited in the literature, war, and taxation, thus turn out to have been of negligible 
importance (Finer 1997; Hintze 1975 [1931]; Maddicott 2010; Poggi 1978; Schumpeter 1991 [1917/1918]; Tilly 1990). More particularly, the analysis lends little support to Bisson's (1966) seminal argument that the early assemblies (preparliaments) that provided the harbinger for representative institutions were originally military in nature. This assertion comes with a caveat. When Bisson touches upon the Crown of Aragon, he seems to subsume land peace as one example of a military purpose (201112). ${ }^{10}$ More generally, one might object that the only difference between dealing with war and with land peace is that the first concerns external military threats, the second internal military threats. However, this difference is in fact fundamental. External warfare requires raising an army whereas the aim of land peace was to secure thesemivoluntary-internal pacification of the realm in a situation in which monarchical power was feeble and private conflicts ubiquitous. Establishing land peace was among the first attempts to impose a centralized enactment of (nonfeudal) law from above. The king did this in his capacity as defensor pacis, "guarantor of the national peace" (Kagay 1988: 61-63).

Turning to later assemblies (and hence to representative institutions), we find some important changes. Most conspicuously, land peace is now a rather infrequent reason for convening assemblies. This can be seen in figure 4 as we find very few late assemblies in which a land peace was established. If we again isolate representative institutions, it turns out that only 13 percent of all such assemblies established a land peace. This development probably reflects the increasing sway of royal power in the thirteenth century, which made it less important to have elites commit to a land peace (Bisson 2009; Mann 1986: chap. 13). The drop in Catalonia is especially striking as only two corts (12.5 percent) were devoted to establishing a pax et treuga whereas most preparliaments had this aim. Meanwhile, succession holds up as a reason for summoning assemblies after they turn representative. No fewer than 18 (29 percent) definitely representative institutions were convoked in the period 1100-1327 because of matters of royal inheritance, making it the most frequent reason for summoning this kind of assembly. Not surprisingly, succession was an especially prominent reason for calling the general assembly of Aragon-Catalonia ( 68 percent $)^{11}$ whereas the purely Catalan corts were only called once ( 6 percent) with this aim. However, both in Aragon (33 percent) and Valencia (27 percent), succession often motivated calling the cortes.

Next, figure 4 shows that war and taxation become much more frequent as reasons for summoning assemblies over time. When we distinguish between preparliaments

10. A few other certain caveats: First, Bisson's (1966) analysis rests mostly on France and England. Second, Bisson focuses mostly on the thirteenth century, a period when (as described in the following text) war and taxation also seem important for representative institutions in the Crown of Aragon. That said, Bisson's purpose is to identify the origins of assemblies, and here, the Crown of Aragon does not fit so well, unless land peace is seen as a military function. I am indebted to one of the anonymous reviewers for suggesting this clarification.

11. More generally, we can note that the summoning of both preparliaments and later representative institutions in the superunit of Aragon-Catalonia(-Valencia) are overwhelmingly related to succession (9 out of 18 assemblies), with land peace as a quite common additional reason in the early period and war a quite common additional reason in the later period. 
and genuine representative institutions, the numbers speak a pretty clear language. War almost matches succession as a reason for convoking representative institutions (15 instances equaling 24 percent of all convocations), and taxation (almost always to finance war) features as the third most prominent reason for summoning representative institutions (13 instances equaling 21 percent of all convocations). To illustrate, we can turn to James I's-aka the Conqueror's-expansionary wars from the late 1220s onward (more in the following text). The first genuine representative institution in Catalonia, the corts at Barcelona in December 1228, was summoned by James to prepare an invasion of Muslim Majorca. More generally, James called a series of assemblies in the period 1225 to 1236 to prepare wars against Muslims, including the campaign against Valencia in the 1230s (Bisson 1986: 64-66; O'Callaghan 1975: 342-47).

One could therefore be tempted to conclude that one reason war and taxation feature so prominently among explanations of the origins of representative institutions is the tendency to read history backward, as noted in the introduction. Scholars might have correctly identified war and taxation as causes for the summoning of genuinely representative institutions but ignored that the earlier assemblies of notables (preparliaments) were called to establish public order and stabilize the succession order.

However, more evidence is needed to corroborate the causal importance of war and taxation for the type switch to representative institutions. Considering the relatively low number of assemblies, there is an inherent danger that the growing importance of these factors is an artifact of the war-prone thirteenth century, where the Aragonese count-kings were embroiled in the Reconquista against the Muslim states in the south of Spain, competed with Christian monarchs in Castile and France, and faced a very serious conflict with the French house of Anjou in Southern Italy (Bisson 1986; O'Callaghan 1975). There are two ways to deal with this. First, we can look more carefully at the Aragonese evidence; second, we can expand the investigation using comparisons with other cases. The paper proceeds by employing both strategies.

\section{Concessions Made by Monarchs}

One concern is how frequent the various reasons apply to assemblies-whether they are preparliaments or representative institutions-another is which of these reasons are associated with the granting of major constitutional concessions. We can elucidate this by scrutinizing the tallies of assemblies in which fixed convocations, veto over the right to declare war, the right to audit expenditure, the right to be in charge of adjudication, and the right to appoint officials were granted.

Table 1 reports cross-tabulations of these constitutional concessions with the different reasons for summoning assemblies. Most important here is fixed convocations. Not only is this the only concession that was granted more than a trivial number of times (eight instances in the data set). The granting of fixed convocations is also extremely important with respect to placing constraints on monarchs as it makes a huge difference whether assemblies could be called at the ruler's whim or whether they 
TABLE 1. Tallies of constitutional concessions, broken down on reasons for summoning assemblies, 1100-1327 (N, \%)

\begin{tabular}{lllllll}
\hline & Land Peace & Succession & Taxation & Coinage & War & Total \\
\hline Fixed convoc. & $1(12.5)$ & $0(0.0)$ & $3(37.5)$ & $2(25.0)$ & $0(0.0)$ & $8(100.0)$ \\
Declare war & $0(0.0)$ & $0(0.0)$ & $0(0.0)$ & $0(0.0)$ & $1(25.0)$ & $4(100.0)$ \\
Audit expend. & $0(0.0)$ & $0(0.0)$ & $1(33.3)$ & $0(0.0)$ & $0(0.0)$ & $3(100.0)$ \\
Adjudication & $0(0.0)$ & $1(20.0)$ & $1(20.0)$ & $0(0.0)$ & $1(20.0)$ & $5(100.0)$ \\
Appointment of officials & $0(0.0)$ & $0(0.0)$ & $2(40.0)$ & $1(20.0)$ & $1(20.0)$ & $5(100.0)$ \\
\hline
\end{tabular}

Note: The percentages in parenthesis measure the proportion of all concessions in the period 1100-1327 that coincided with each of the five reasons for summoning assemblies. "Total" denotes the absolute number of each concession.

had become permanent institutions that the ruler had to convoke at regular intervals (say, annually, biennially, or triennially) (cf. Kagay 1997: 32).

Based on table 1, a couple of important observations can be made. Most strikingly, establishing land peace and dealing with succession hardly ever coincide with constitutional concessions. The main reason for the first result is that land peace, as we have seen, was most important early on whereas the prerogatives were only granted in the second part of the analyzed period, once preparliaments had evolved into representative institutions. However, when it comes to succession, which also occasioned a large number of "late" assemblies, the result is striking. This does not mean that no concessions were granted at assemblies dealing with succession. Indeed, the usual pattern was that the new king reconfirmed traditional privileges (the fueros of Aragon, furs of Catalonia, fueros of rural Valencia, and furs of urban Valencia). But it is these more regular concessions, which do not relate to the assemblies as such, and not the exceptional prerogatives listed in table 1 that correlate with succession. ${ }^{12}$

To the extent that any pattern can be identified, it is that the increase in prerogatives in general and the concession of fixed convocations in particular were relatively often related to taxation (in the form of either general taxation or grants made against a promise not to debase coinage). Next, it is worth noting that constitutional concessions virtually always occurred at the level of the subunits; that is, in Aragon, Catalonia, and Valencia. For the superunit of Aragon-Catalonia(-Valencia), we only find two examples of constitutional concessions, and we do not we find a single example of the promise of fixed convocations. This underscores that the most important relationships between rulers and elite groups in the Middle Ages were anchored on a local level (Blicke 1997; Sabetti 2004; Zagorin 1982: 109).

The absolute tallies are so low that it is somewhat tenuous to generalize about the relationship between particular reasons for summoning assemblies and the extension of prerogatives. Against this background, we learn more by breaking the expansion of prerogatives down on the three time periods identified in the preceding text, when

12. In the data set, the confirmations of fueros/furs have been registered under the "other" category mentioned earlier. 
TABLE 2. Tallies of constitutional concessions and assemblies, broken down on different time periods $(N, \%)$

\begin{tabular}{lllllll}
\hline & $\begin{array}{l}\text { Fixed } \\
\text { Convocations }\end{array}$ & Declare War & $\begin{array}{l}\text { Audit } \\
\text { Expenditure }\end{array}$ & Adjudication & $\begin{array}{l}\text { Appointment } \\
\text { of Officials }\end{array}$ & $\begin{array}{l}\text { Number of } \\
\text { Assemblies }\end{array}$ \\
\hline $1217-36$ & $0(0.0)$ & $0(0.0)$ & $0(0.0)$ & $0(0.0)$ & $0(0.0)$ & $18(16.8)$ \\
$1275-93$ & $4(50.0)$ & $4(100.0)$ & $0(0.0)$ & $2(40.0)$ & $4(80.0)$ & $30(28.0)$ \\
$1307-25$ & $2(25.0)$ & $0(0.0)$ & $2(66.7)$ & $1(20.0)$ & $1(20.0)$ & $15(14.0)$ \\
$1100-1327$ & $8(100.0)$ & $4(100.0)$ & $3(100.0)$ & $5(100.0)$ & $5(100.0)$ & $107(100.0)$ \\
\hline
\end{tabular}

Note: The percentages in parenthesis measure the proportion of all concessions (and number of assemblies) in the period 1100-1327 that were conceded in each period.

the activity of assemblies was highest. As illustrated in table 2, the great majority of expansions of prerogatives occurred in the two last of these periods, 1275-93 and 1307-25. Indeed, most expansions took place in the short period between 1275 and 1293. Recall the earlier observation that the first of the three periods, 1217-36, was the one in which the type switch from preparliaments to representative institutions occurred. Taken together, these observations underline that anyone wishing to understand the causes of the development of representative institutions in the Crown of Aragon needs to study these three periods in general and the period between 1275 and 1293 in particular.

\section{The Priority of Warfare}

What does a closer look at the three periods mentioned in table 2 reveal about the causes of the development of representative institutions in the Crown of Aragon?

To start with the conclusion, warfare features as crucial for understanding these developments. The first period, 1217-36, comprises most of the early reign of the aptly named count-king James the Conqueror. Even the prelude to James's reign was all about war. The Conqueror-to-be inherited the throne in 1213 following his father Peter II's defeat and death at the hands of Simon de Montfort (senior) at Muret in September that year (Bisson 1986: 38-40). James's early reign was dominated by noble unrest. But upon reaching his majority, his career as conqueror began. After a false start in the summer of 1225, where James failed to take the frontier castle of Peniscola in the kingdom of Valencia, he managed to conquer the Balearic Islands in 1229-35. This was followed by a renewed offensive against the Muslim state of Valencia from 1232, which led to the conquest and annexation of that kingdom in 1238.

Many of the assemblies taking place during the period from 1225 to 1238 were used to secure subsidies for warfare from the towns (Abulafia 1999: 645-46; Bisson 1986: 79-80; Kagay 1981: 67-73, 77-82). As mentioned previously, a corts was 
called in Barcelona in December 1228 to prepare the attack on the Balearic Islands. Another one-covering both Aragon and Catalonia-was summoned at Monzon in December 1232 to prepare for an invasion of Muslim Valencia; just as a previous Catalonian assembly had been called in Tortosa in April 1225 to prepare the failed attack on Peniscola (Kagay 1981: 83-88, 96-105; Bisson 1966: 1206; 1986: 64-66; O’Callaghan 1975: 342-47).

Fast-forward to the period after 1275 and warfare is even harder to ignore as an explanatory factor. James's conquests had stoked internal opposition in especially Aragon, and his failure to call very many assemblies during the second part of his long reign further fueled the flames (Abulafia 1999: 660). As James lay dying, the Aragonese nobles and towns were already up in arms (Bisson 1986: 73). James's son Peter III did nothing to appease these sentiments when, five years into his reign, he used the Sicilian Vespers of 1282 as an occasion for snatching Sicily from the House of Anjou. This spectacular foreign policy coup came at a high price as the Crown of Aragon was embroiled in conflict with the French Angevins, the French pope Martin IV, the French king, and eventually also Castile (Kagay 1981: 213; O'Callaghan 1975: 387-88). The Angevins held on to Naples and attempted to recover Sicily by force. Meanwhile, the pope excommunicated Peter, and in 1285, the French king invaded Catalonia. Against such a coalition of forces, the very existence of the Crown of Aragon was threatened (Bisson 1986: 88).

In this situation of peril, Peter was forced to come to terms with the internal opposition in Aragon and Catalonia. This took place in two different ways. In Aragon, the nobles and towns-with the nobles as the senior partner and most uncompromising group - rebelled and had to be appeased by two rounds of royally granted privileges: the Privilegio General granted by Peter in October 1283 in Zaragoza and the Privilegios de la Union granted by Peter's successor Alfonso III at Zaragoza in January 1288 (O'Callaghan 1975: 394-95). These concessions were given at the edge of a blade. In Catalonia, Peter was able to placate sentiments by granting concessions before the nobles and towns took up arms. However, the result was a set of constitutional concessions similar to the ones in Aragon (Kagay 1981: 189; Marongiu 1968: 68-69; O’Callaghan 1975: 389).

Let's push a bit more at these events that reveal a great deal about the way war facilitated political constraints on monarchs. At a cortes at Tarazona in September 1283, the Aragonese nobles protested that they had not been consulted over Peter III's conquest of Sicily the year before and that they were being unlawfully taxed. Backed by important Aragonese towns, the nobles recreated the so-called Aragonese Unión, the aim of which was to anchor control over the king's administration in the cortes. At the next cortes-Zaragoza in October 1283-the Unión succeeded in getting Peter to promise to transform the cortes from an assembly summoned at the king's initiative to a permanent public institution (Kagay 1981: 167-78). In Catalonia, the corts at Barcelona in December 1283 granted Peter extraordinary funding for the French wars - but at a high price. First, the Catalans similarly extracted the promise of annual convocations; second, they stipulated that the taxes were to be collected by members of the corts. 
More generally, warfare facilitated the development of representative institutions in both a direct and an indirect way. To illustrate the direct mechanisms, we can observe that the larger wars of the late thirteenth and fourteenth century made Aragonese count-kings completely dependent on the cortes/corts to secure the wherewithal for their armies. This was the situation both during the Mediterranean conquests and when the French invaded in 1285 . To illustrate the more indirect mechanisms, the countkings often did not wish to divert military resources to counter baronial opposition when they were campaigning and instead chose to accommodate the rebels. For instance, this was James the Conqueror's policy in 1264-65, where he was engaged in crushing a Muslim insurrection in Castile and, rather than send in his army, chose to grant the Aragonese Unión the so-called fueros of Exea and establish the ombudsman office of the Justicia (Kagay 1988: 69-70).

However, there are also some caveats to the arguments about the preeminence of warfare for the political developments in the three periods. First, warfare figures less prominently in the third of the three periods, 1307-25. It is not that these were decades of peace. In 1308, King James II began a war with the Muslim state of Granada that was not brought to an end until 1323. The period also includes the conquest of Sardinia initiated in 1322 and completed in 1326 (Bisson 1986: 95-96). Nonetheless, the level of warfare was clearly less intense in these decades, and the kings were not threatened from the outside in the same way as in the period after 1282. Second, there is no perfect overlap between warfare and even the first two periods. For instance, James the Conquerors minority (1213-24) was a relatively peaceful period with respect to external warfare, the real action only began 1225 . Hence, the assembly activity and advent of representative institutions in the period 1217-36 might owe both to the minority — which always placed the crown in dire straits (Kagay 1988: 62) — and to the later warfare.

Third, the Crown of Aragon was also engaged in wars in the periods when no constitutional concessions were granted. We can illustrate this by turning to an equally aptly named Aragonese king, Alfonso I, the Battler, who ruled from 1104-34, and who was involved in numerous wars across Spain and in Southern France. The reason that this left little trace in assembly activity might be that the wars of the Battler simply took place before assemblies had caught on. Alternatively, there might be an important difference between the landlocked wars of the Battler and the later seaward offensives of the Conqueror. Securing backing from especially the townsmen of Barcelona was much more important when the aim was to raise fleets that could carry the theater of war to the Balearics and (later) to Sicily and Sardinia than when battling in the Iberian interior.

These nuances are important but they do not alter the main patterns. Details aside, the most intense geopolitical episodes of the investigated period clearly fall in the first decades of James the Conqueror's majority and in the last two decades of the thirteenth century, that is, in the two first periods identified in the preceding text (see also Bisson 1986). Most importantly, the years after 1282 where we find so many monarchical concessions are idiosyncratic because the very existence of the Crown of Aragon was endangered. The consequences of the upheavals between 1282 and 1287 were that 
the cortes and corts became an integrated part of the body politics as an estate pole opposing royal power (ibid.: 90). During the reign of James II (1291-1327) this found expression in a dualistic regime form where the cortes of Aragon and corts of Catalonia partook in legislation and government as permanent political institutions (Kagay 1981: $244,355,368)$. The main record therefore stands: the thirteenth- and early-fourteenthcentury constitutional concessions in the Crown of Aragon tended to occur against the ramification of warfare. In this respect, some of the fundamental insights of previous research on the development of representative institutions travel well to this case once we focus on the type switch from preparliaments to representative institutions and the later expansion of parliamentary prerogatives (see Finer 1997; Hintze 1975 [1931]; Poggi 1978; Schumpeter 1991 [1917/1918]; Tilly 1990).

\section{Beyond Aragon: England in the Thirteenth Century}

It has already been observed that England is probably the second best place to analyze the origins of representative institutions. As the Crown of Aragon, it is an early instance on which we have good data on assemblies. According to historians, the development of the English parliament begins in earnest with the Magna Carta of 1215, and a good century later-around 1330 at the latest - the institution come to be known as the "king-in-parliament" had come into existence (Finer 1997: 1039; Maddicott 2010: vii; Marongiu 1968: 92).

I have attempted to gather data similar to those on the Crown of Aragon for this period. These data come from two different sources: Maddicott (2010: 454-72) and Handbook of British Chronology (henceforth Handbook; Fryde 1986), respectively. The former source provides exhaustive descriptions of all assemblies in the short period from 1235 to 1257 . The latter covers all assemblies after 1216 but only provides narrative descriptions, which makes it possible to score the causes of summoning, for the period 1216-60; after this point, it only contains information on date, place, and the groups summoned.

Starting with the entire period from 1216 to 1330, a total of 211 assemblies can be attested according to the Handbook. As illustrated in figure 5, the first representative institution can be dated to 1265 , meeting at London on January 20. We find two more representative institutions in the 1270s, but not until 1295 onward are burgesses and knights-of-shires regularly summoned as representatives of their localities. The thirteenth century almost solely contains preparliaments. Regarding group attendance, nobles partake in virtually all assemblies and the clergy in most. The knights-of-shires make their first appearance in 1258 but are only called regularly from the $1290 \mathrm{~s}$ onward. Much the same can be said for the townsmen, who first appear in 1265, appear sporadically in the following decades, and then regularly after 1295.

To clarify the scoring, we find several assemblies between 1265 and 1295 in which burgesses and/or knights-of-shires attended but, according to the Handbook, not as representatives of the localities, just as we find assemblies before 1265 in which knights-of-shires attended and even a few after 1295 in which townsmen attended 


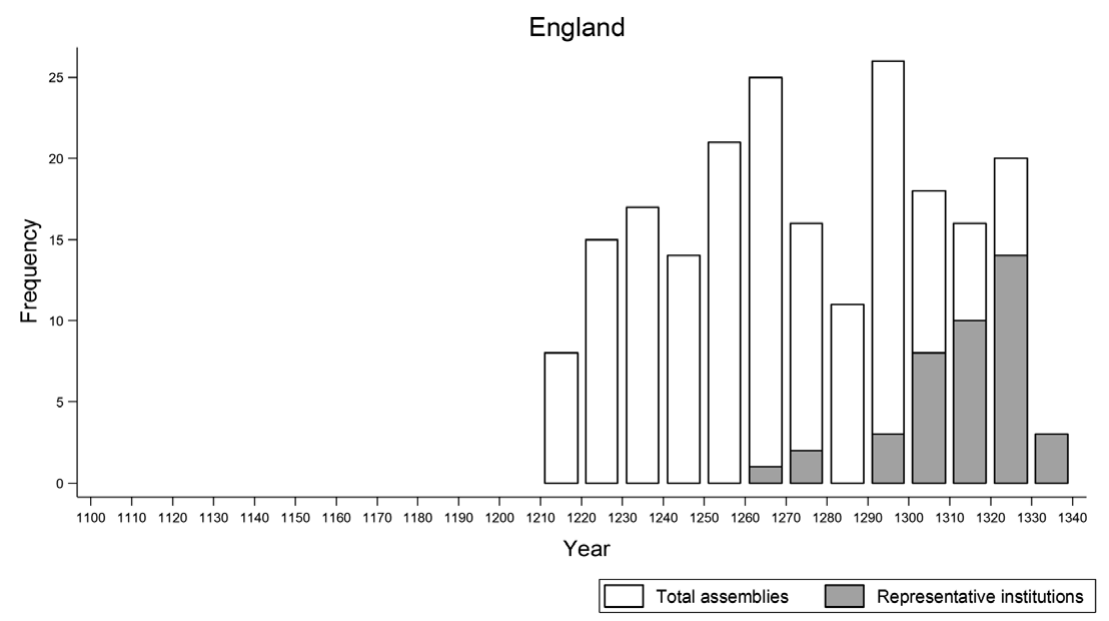

FIGURE 5. Preparliaments and representative institutions by decade, England, $1216-1330$.
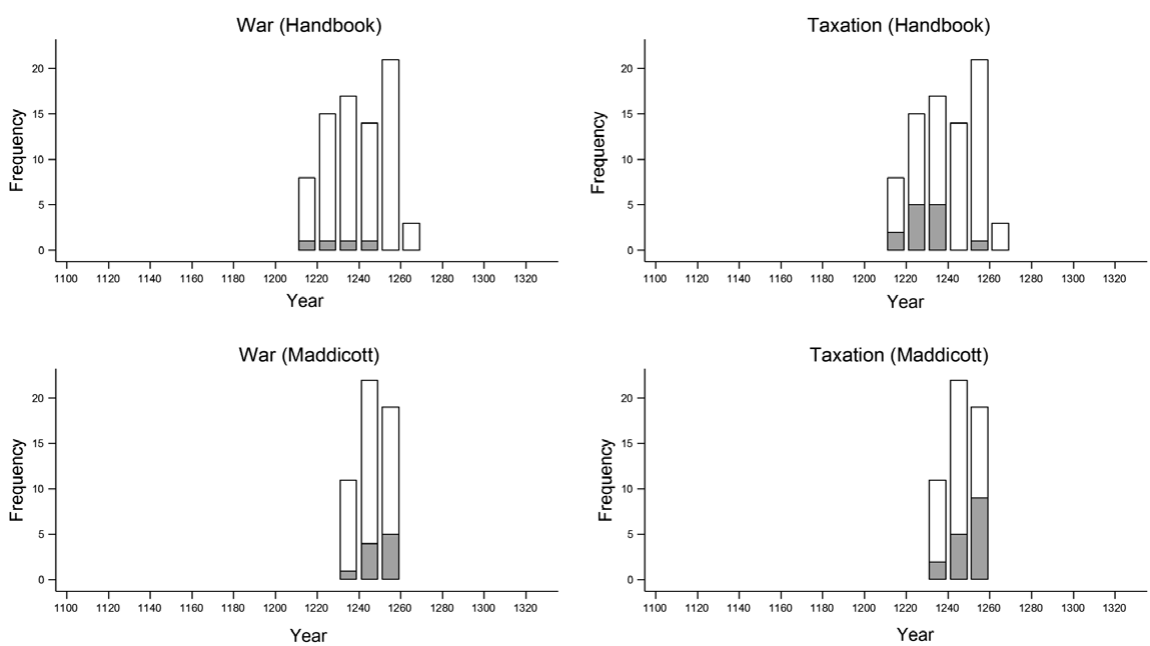

FIGURE 6. Reasons for summoning assemblies by decade, England, according to Handbook (1216-60) and Maddicott (1235-57), respectively.

without a proctorial mandate. As in the case of the Crown of Aragon, these assemblies are not tallied as representative institutions.

Delimiting attention to the more exhaustive Handbook data for the period from 1216 to 1260 , we find no evidence that the English king granted any of the prerogatives that we find in Aragon. More interesting are the reasons for summoning assemblies. As illustrated in figure 6, the data based on the Handbook show that taxation and warfare 
are by far the dominant reasons for convoking assemblies in this period. Out of the 79 assemblies summoned in the period 1216-60, 13 (16.5 percent) were convoked by King Henry III to request extraordinary taxation. On top of this, four assemblies (5 percent) centered on warfare. Strikingly, according to the Handbook, we find only one assembly establishing an equivalent of the Aragonese/Catalonian land peace, and only three dealt with matters of succession (these low frequencies are not illustrated in figure 6). The last result is to some extent an artifact of King Henry III ruling throughout this period, which for most of the time laid the matter of succession mute. Tellingly, the two very first assemblies - in Gloucester, October 26-27, 1216 and in Bristol, November 11-12, 1216-were convoked to settle Henry's ascension to the throne. Therefore, succession is likely to be more important if the data had covered periods with different monarchs, including shorter ruler spells than the 57 years reign of Henry III.

Turning to Maddicott's (2010: 454-72) even more exhaustive descriptions of $52^{13}$ assemblies between 1235 and 1257, the same pattern is identified, but it is much starker. As illustrated in figure 6, no less than 16 (31 percent) of these assemblies dealt with taxation and no less than 10 (19 percent) with warfare. No other "reasons" categories can be ticked for this period, but Maddicott's descriptions show that no less than four of the assemblies actually dealt with the appointment of royal officials; this is not registered in the Handbook descriptions.

We should be careful not to read too much into these data considering that they only cover one reign, namely that of Henry III. That said, the data indicate that taxation and warfare are more important for the early development of the English parliament than for the early development of the cortes/corts in the Crown of Aragon. Vice versa, succession and land peace are much less prominent in England. Furthermore, it is worth noting that - based on both data sources - we find a series of examples of assemblies refusing to grant the taxes requested by King Henry III. For the Maddicott data, this actually occurs 11 out of the 16 times (69 percent) taxation is on the agenda. ${ }^{14}$ The magnates could not refuse a tax if it was deemed necessary, for instance, for defending the realm. However, they could and did dispute this necessity, and they regularly refused with reference to the tax not being necessary, for example, because its aim was to campaign abroad (normally in France) (Harriss 1975: 30-38; Maddicott 2010: 170-75; Marongiu 1968: 83). Though this was less common in the Crown of Aragon, we do find some similar examples. For instance, in 1305 James II invoked the necessity clause to secure Catalan funding for his planned campaign against Sardinia but the Catalans refused by arguing that this offensive campaign was not designed to defending the realm (Kagay 2003: 71-72).

The conventional wisdom about the development of representative institutions, which relates this to constitutional conflicts over taxation in the context of geopolitical pressure, thus holds up more strongly in the English case (but see

13. The Handbook only registers 33 assemblies in this period.

14. It should be kept in mind that a central thesis for Maddicott (2010) is that conflict over taxation explains the emergence of the English parliament. Hence, there is a risk of confirmation bias when using his descriptions to score the reasons for summoning assemblies. 
Boucoyannis 2015). More particularly, this relationship characterizes even the preparliament phase, whereas in the Crown of Aragon it was only relevant for the type switch to representative institutions and their later expansion of prerogatives. This places the Aragonese development in a comparative perspective as it goes to show that public order might not everywhere have been the main cause for the birth of representative institutions.

The comparison thereby raises a series of important research questions: Is the English development representative of the more general development of preparliaments? Or have prior scholarships inferred from what is in fact an exceptional case, with the Iberian development being more representative? One possibility here is that the English case differs because this is the realm where twelfth- and thirteenth-century kings had the most power (cf. Boucoyannis 2015), meaning that Plantagenet kings might have had the capacity to keep public order even without resorting to assemblies. In this connection, the comparison between internally stable England and the Iberian Peninsula is especially stark as the Reconquista created a great deal of instability and meanwhile empowered social groups in various ways, for example, through the frontier tenancies granted to nobles and military orders and the charters used to attract Christian settler to towns in conquered areas (Bisson 1986: 17, 33, 42-45; 2009: 97100; O'Callaghan 1975: 288, 240, 467-90).

Finally, note the striking resemblances in periodization in England and the Crown of Aragon. In the English case, three important periods can be identified: 1216-27 (Henry III's minority), 1258-67, and 1307-27 (see also Maddicott 2010; Marongiu 1968: 79). Compare with the three crucial Aragonese periods: 1217-36, 1275-93, and 1307-25. Even though the overlap is not perfect, we are still dealing with what must surely be seen as a surprising historical Parallelismus.

There are at least two possible ways of explaining this. First, the case might be that broader dynamics operate. For instance, Maddicott (2010: 106) observes that in a number of European kingdoms, "the late twelfth and early thirteenth centuries proved to be an era of particular political unrest" caused by "war, royal taxation, demands for military service, and disputes over rights of consultation." If such pan-European geopolitical dynamics operate, it could explain similarities in the timing of crucial periods. Second, the case might be that key aspects of constitutional development in the two realms reflect patterns of diffusion of ideas and institutions (as briefly mentioned in the "A New Data Set on Assemblies in the Crown of Aragon" section). For instance, historians have documented that the Magna Carta of 1215, which has been identified as the impetus for the advent of the English Parliament in the thirteenth century (Maddicott 2010), was inspired by similar charters in "those parts of Spain and southern France where king John had been diplomatically most active in the years before 1215" (Vincent 2012: 62). There is in fact a larger body of research by historians that discusses the similarities between the development in thirteenth-century Aragon and England and come down in favor of either the existence of common "background factors" or some kind of "cross-pollinization" (Kagay 1988: 71). This, too, would be interesting to probe in future comparative research done by social scientists. 


\section{Taking Stock of the Findings}

The empirical findings of this paper challenge some aspects and corroborate other aspects of the most influential present explanations for the rise of representative institutions. The most important challenge concerns the causes of the original birth of the assemblies that were to become representative. In the Crown of Aragon, public order-more particularly the establishment of land peace and the regulation of succession-features as the most important reason for the convocation of the assemblies of notables that gradually turned into representative institutions.

This conclusion ties well with the observation that assemblies were initially an instrument used by the ruler to achieve certain aims, not a set of constraints on rulers created by potent social forces. Only much later on did they metamorphose into an instrument that allowed elite groups to rein in rulers. However, the finding is nonetheless at odds with most of the recent literature, which has not adopted this premise but rather focused on the way assemblies allowed elite groups to rein in rulers. The insights about the original regalian initiative, even though they have been mentioned in many monographs written by historians, have been ignored in comparative work, probably due to the tendency to read history backward from the representative institutions that came to constrain rulers.

Turning to this later metamorphosis, in the case of the Crown of Aragon, it was narrowly connected with war and taxation; that is, the standard explanations of the dominant geopolitical or fiscal perspective on the origins of representative institutions prove their worth at a later stage of the development. These external pressures empowered elite groups because the monarch depended on them to secure the wherewithal and manpower for warfare. It was against this backdrop that monarchs accepted that the representative institutions began to constrain their rule in formal terms. This indicates that the mechanisms posited by the geopolitical perspective are much better at accounting for the consolidation than for the origins of representative institutions (Bisson 1966; Finer 1997; Hintze 1975 [1931]; Poggi 1978; Schumpeter 1991 [1917/1918]; Tilly 1990).

Next, this twofold finding might be said to partly corroborate and partly challenge Boucoyannis's (2015) recent criticism of fiscal perspectives. Boucoyannis argues that a high level of state capacity was a precondition for establishing representation. The analysis presented in the preceding text shows that early assemblies in the Crown of Aragon were very much a "child of the monarchy" (Kagay 1981: 360). This aligns well with Boucoyannis's so-called compellence model, the core argument of which is that monarchs forced representation upon groups to ensure that they would stand by the decisions made at assemblies. However, to reiterate, in the Crown of Aragon, the main aim of the early assemblies was to secure (semivoluntary) public order because of the weakness of royal power. And when the question of taxation did arise, as a consequence of geopolitical pressure, it did indeed empower elite groups vis-à-vis monarchs, reflected in the granting of what I have termed constitutional concessions. England clearly makes a better fit with Boucoyannis's (2015) claims about the powerful regal initiative that looms behind and exercises control over proctorial 
representation with the aim of committing elites. But as pointed out in the preceding text this might be a consequence of the relatively high levels of royal power in the Plantagenet realm, meaning that the English case might not be easily generalized to Continental Europe, or at least not to the conflict-prone Iberian Peninsula. Furthermore, we have seen that war and taxation became key issues at Henry III's assemblies. This shows that some of the geopolitical/fiscal dynamics operated at an early stage in the development of the English parliament.

What does the analysis reveal about the more particular theories about the origins of representative institutions mentioned in the introduction? At first sight, there is quite some support for Stasavage's (2010) theory about geographical distance as a main hindrance for vibrant assemblies. The analysis shows that assemblies for the superunit of Aragon-Catalonia(-Valencia) never really caught on. In fact, the data set clearly shows that these were exceptional occurrences, normally linked to warfare. The more regular assemblies tended to take place in the subunits of Aragon, Catalonia, and Valencia. However, the findings might also be interpreted in a different way, which challenges Stasavage's story. The analysis raises the question whether Stasavage's finding might be an artifact of the fact that key relationships between rulers and society took place on a local level in medieval and early modern Europe for reasons not related to geography but rather to what Blicke (1997) terms "communalism" (see also Sabetti 2004; Te Brake 1998). The distances to be traveled were not forbidding in the Crown of Aragon (at least not with respect to the Iberian possessions covered in this paper). But rights-both of rulers and elite groups-nonetheless remained anchored on the local level, that is, on the level of the subunits.

To illustrate, though we do find some judicial integration after the unification of the crowns of Aragon and Catalonia in 1137, the two legal systems retained their different characters (Kagay 1988: 65). It is furthermore telling how often nobles and townsmen especially in Aragon protested against Catalonian influence, including the use of Catalan furs instead of Aragonese fueros in Valencia and royal appointments of non-Aragonese in Aragon. For instance, one of the motivations behind the aforementioned Aragonese revolt in 1264 was the perceived Catalanization of Aragonese institutions, including the appointment of Catalans and Provencals in the Aragonese judicial system (ibid.: 67). Also, while we find numerous examples of leagues of nobles and/or townsmen in both Aragon and Catalonia, we find few examples of such leagues being established by nobles and/or towns across the two units (ibid.: 66). Stasavage's (2010) own prime example, France, might reflect similar dynamics as it was not so much the distances as the fact that rights were of a local nature, which made rulers rely on regional rather than "national" representative institutions. Moreover, the findings underscore that the use of aggregate units that most of the recent literature has resorted to is generally problematic and that, in particular, it is paradoxical that Stasavage (2010) uses aggregate units such as "Spain" in his attempt to test the effects of distance.

With respect to the elite groups that were most influential in shaping the development of representative institutions, matters are more complicated. The communal revolution does feature as important because the shift to representative institutions 
is very much associated with the attempt of monarchs to give urban representation a proctorial status to make sure that town councils felt obligated by decisions emanating from assemblies, particularly concerning tax grants. This does provide some evidence in favor of the rise of the towns as important for the type switch to representative institutions (Poggi 1978; Van Zanden et al. 2012). ${ }^{15}$ However, the development of parliamentary constraints was very much a product of townsmen and nobles presenting a united front against monarchs, with the nobles as the senior partner. In that respect, there is also some support for the notion, prominent in authors such as Montesquieu and Tocqueville and later picked up by a large literature on feudalism, that the European nobility was instrumental for reining in monarchs (Blaydes and Chaney 2013; see also Møller 2016). While the rise of the towns is most important for turning assemblies into representative institutions, the opposition of the nobles seems to be a core cause of the later development of constraints on the executive. We find less evidence of the clergy playing the key role attributed to it by, for example, Hintze (1975 [1931]), but this obviously does not rule out a more general-latentimportance of the medieval conflicts between secular and religious powers. In this respect, it is worth recalling that the development that was to produce secular representative institutions did not begin in earnest until after the Gregorian revolution had undermined theocratic notions of kingship, including the legitimacy of rulers convoking ecclesiastical assemblies (Southern 1970: 34, 96; Ullmann 1977: 22-23).

\section{Conclusions}

Research on representative institutions has had a solid foothold in medieval studies for generations. Assemblies have attracted "perhaps more scholarly attention than any other subject within the institutional history of medieval Europe" (Cerda 2011: 62). In the latest decade, they have also made a spectacular entry in political science and economics, spurred by the economic and political effects attributed to European institutions of constraints on the executive. The next step for this new research agenda is to connect with historians' prior scholarship. ${ }^{16}$

This paper demonstrates some of the benefits that can be derived from making such a connection. By interrogating a new data set on assemblies in the Crown of Aragon from 1100 to 1327, we have learned several important things about the early

15. As Boucoyannis (2015: 307) observes, the summoning of magnates, who only represented themselves, could only create the institution of medieval assemblies; it was the summoning of the Commons, standing for localities, that created representation.

16. In this connection, a note on the historical work on medieval assemblies is pertinent. Much of the recent work of historians refrains from making general conclusions about the causes of representative institutions. Whereas the question of the origins of representative institutions was a core focus of historians as recently as the decades after World War II, in recent decades, most historians have been unwilling to engage in this kind of explanatory analysis out of a fear of the conceptual anachronism they often see in social science more broadly. This is a pity as it widens the gulf between social science and history. The need for social scientists and historians to link up their work is thus very much a mutual one. I am indebted to one of the anonymous reviewers for suggesting this clarification. 
development of representative institutions. The most important conclusion that emerges from the analysis concerns the role of geopolitical factors (war and taxation) for the development of representative institutions. In the Crown of Aragon, war and taxation were of negligible importance in the early stages of the development that culminated in representative institutions. The establishment of land peace was the most important reason for convoking the preparliaments that predated representative institutions whereas succession was an important reason for summoning both preparliaments and genuine representative institutions. However, once we displace focus to representative institutions, taxation becomes much more prominent as a cause. And when we hone in on the crucial periods when prerogatives were granted, warfare looms as the major explanatory factor. Warfare and taxation therefore figure as crucial for understanding both the type switch to representative institutions and their later expansion of prerogatives. On top of this, we can note that in England, warfare and taxation were also important in the preparliament phase.

Several other observations are worth highlighting. First, it has been demonstrated that in the Crown of Aragon the crucial developments bringing about representative institutions occurred in brief bursts, with the type shift from preparliaments occurring in the 1220 s and the main expansion of parliamentary prerogatives in the period 1275-93. Second, and intriguingly, it has been shown that the crucial decades of constitutional development in England virtually overlap with those in the Crown of Aragon; this calls for comparative inquiries.

These observations illustrate the shortcomings of extant data sets on medieval and early modern European representative institutions. The aggregate time periods and aggregate units employed in these data sets serve to hide the important events that have been identified in the analysis of the Crown of Aragon. Most importantly, the period between 1275 and 1293 emerges as a sine qua non episode for understanding the development of representative institutions in the Crown of Aragon. It was during this brief span of time - and in the 1280s in particular - that the tracks that would lead to the pactist monarchy of the fourteenth and fifteenth centuries were laid. This was a regime form where especially the Aragonese cortes and the Catalan corts, organized in four or three estates (brazos), had great influence in most matters of state, including even foreign and financial policy (see Kagay 1981: 384-85, 392; Myers 1975: 62-65). It probably took an exogenous shock such as the geopolitical pressure unleashed by Peter III's conquest of Sicily to create this development. But this insight would be virtually impossible to garner based on extant data sets that code assemblies over half a century or an entire century.

\section{References}

Abramson, Scott, and Carles Boix (2014) The Roots of the Industrial Revolution: Political Institutions or (Socially-Embedded) Know-How? Working Paper, Princeton University.

Abulafia, David (1999) "The rise of Aragon-Catalonia," in David Abulafia (ed.) The New Cambridge Medieval History V. Cambridge: Cambridge University Press: 644-67. 
Acemoglu, Daron, and James Robinson (2012) Why Nations Fail: The Origins of Power, Prosperity, and Poverty. New York: Crown Business.

Acemoglu, Daron, Simon Johnson, and James Robinson (2001) "The colonial origins of comparative development: An empirical investigation." American Economic Review 91 (5): 1369-1401.

(2002a) "Reversal of fortune: Geography and institutions in the making of the modern world income distribution." Quarterly Journal of Economics 117 (4): 231-94.

(2002b) "The rise of Europe: Atlantic trade, institutional change and economic growth." Massachusetts Institute of Technology, Department of Economics, Working Paper No. 02-43.

Bisson, Thomas N. (1966) "The military origins of medieval representation." The American Historical Review 71 (4): 1199-1218.

(1986) The Medieval Crown of Aragon: A Short History. Oxford: Clarendon Press.

(2009) The Crisis of the Twelfth Century: Power, Lordship, and the Origins of European Government. Princeton, NJ: Princeton University Press.

Blaydes, Lisa, and Eric Chaney (2013) "The feudal revolution and Europe's rise: Political divergence of the Christian west and the Muslim world before 1500 CE." American Political Science Review 107 (1): 16-34.

Blicke, Peter (1997) Resistance, Representation, and Community. Oxford and New York: Clarendon Press.

Boucoyannis, Deborah A. (2015) "No taxation of elites, no representation: State capacity and the origins of representation." Politics and Society 43 (3): 303-32.

Capoccia, Giovanni, and Daniel Ziblatt (2010) "The historical turn in democratization studies: A new research agenda for Europe and beyond." Comparative Political Studies 43 (8-9): 931-68.

Cerda, José Manuel (2011) "The assemblies of Alfonso VIII of Castile: Burgos (1169) to Carrión (1188)." Journal of Medieval Iberian Studies 3 (1): 61-77.

Downing, Bryan M. (1992) The Military Revolution and Political Change: Origins of Democracy and Autocracy in Early Modern Europe. Princeton, NJ: Princeton University Press.

Ertman, Thomas (1997) Birth of the Leviathan: Building States and Regimes in Medieval and Early Modern Europe. Cambridge: Cambridge University Press.

Finer, Samuel E. (1997) The History of Government II: The Intermediate Ages. Oxford: Oxford University Press.

Fryde, E. B., D. E. Greenway, S. Porter, and I. Roy (1986) Handbook of British Chronology, 2nd ed. London: Offices of the Royal Historical Society.

Hariri, Jacob G. (2012) "The autocratic legacy of early statehood." American Political Science Review 106 (3): 471-94.

Harriss, G. L. (1975) King, Parliament, and Public Finance in Medieval England to 1369. Oxford: Clarendon Press.

Hintze, Otto (1975 [1931]) "The preconditions of representative government in the context of world history," in The Historical Essays of Otto Hintze. New York: Oxford University Press: 302-53

Jones, Eric (2008 [1981]) The European Miracle: Environments, Economies and Geopolitics in the History of Europe and Asia. Cambridge: Cambridge University Press.

Kagay, Donald Joseph (1981) “The development of the cortes in the Crown of Aragon, 1064-1327." ETD Collection for Fordham University.

(1988) "Structures of baronial dissent and revolt under James I (1213-76)." Mediaevistik 1: 61-85.

(1997) "Rebellion on trial: The Aragonese Unión and its uneasy connection to royal law, 1265-

1301.” Journal of Legal History 18: 30-43.

(2003) "The national defense clause and the emergence of the Catalan state: Princeps namque revisited," in Donald J. Kagay and L. J. Andrew Villalon (eds.) Crusaders, Condottieri, and Cannon: Medieval Warfare in Societies around the Mediterranean. Leiden, The Netherlands, and Boston: Brill: 57-97.

Maddicott, John R. (2010) The Origins of the English Parliament, 924-1327. Oxford: Oxford University Press. 
Mann, Michael (1986) The Sources of Social Power: A History of Power from the Beginning to A.D. 1760. Cambridge: Cambridge University Press.

Marongiu, Antonio (1968) Medieval Parliaments: A Comparative Study. Vol. 32. London: Eyre and Spottiswoode.

Møller, Jørgen (2014) "Why Europe avoided hegemony: A historical perspective on the balance of power." International Studies Quarterly 58 (4): 660-70.

(2016) "Composite and loose concepts, historical analogies, and the logic of control in comparative historical analysis." Sociological Methods \& Research 45 (4): 651-77.

Myers, A. R. (1975) Parliaments and Estates in Europe to 1789. London: Thames and Hudson.

O'Callaghan, Joseph F. (1975) A History of Medieval Spain. Ithaca, NY, and London: Cornell University Press.

(1989) The Cortes of Castile-Léon 1188-1350. Philadelphia: University of Pennsylvania Press.

Poggi, Gianfranco (1978) The Development of the Modern State: A Sociological Introduction. Stanford, CA: Stanford University Press.

Procter, Evelyn S. (1980) Curia and Cortes in León and Castile 1072-1295. Cambridge: Cambridge University Press.

Sabetti, Filippo (2004) "Local roots of constitutionalism." Perspectives on Political Science 33 (2): 70-78.

Schumpeter, Joseph A. (1991 [1917/1918]) "The crisis of the tax state," in Richard Swedberg (ed.) Joseph A. Schumpeter: The Economics and Sociology of Capitalism. Princeton, NJ: Princeton University Press: 99-140.

Southern, R. W. (1970) Western Society and the Church in the Middle Ages. New York: Penguin Books.

Stasavage, David (2010) "When distance mattered: Geographic scale and the development of European representative assemblies." American Political Science Review 104 (4): 625-43.

(2011) States of Credit: Size, Power, and the Development of European Polities. Princeton, NJ: Princeton University Press.

- (2016) "Representation and consent why they arose in Europe and not elsewhere." Annual Review of Political Science 19: 145-62.

Te Brake, Wayne (1998) Shaping History: Ordinary People in European Politics, 1500-1700. Berkeley: University of California Press.

Tilly, Charles (1990) Coercion, Capital, and European States AD 990-1990. Cambridge: Basil Blackwell. Ullmann, Walter (1977) Medieval Foundations of Renaissance Humanism. London: Paul Elek.

Van Zanden, J. L., E. Buringh, and M. Bosker (2012) "The rise and decline of European parliaments, 1188-17891." The Economic History Review 65 (3): 835-61.

Vincent, Nicholas (2012) Magna Carta: A Very Short Introduction. Oxford: Oxford University Press. Zagorin, Perez (1982) Rebels and Rulers, 1500-1660. Cambridge: Cambridge University Press. 